\title{
NEWS
}

\section{LOOK FOR MARGALEF'S WRITTEN CONTRIBUTIONS}

Ramon Margalef (1919-2004) was one of the most relevant ecologists of the XX century and arguably was, together with Eugene Odum, the most complete and versatile ecologist of our time. Margalef published profusely during his lifetime. His contributions include scientific papers, books, monographs, meeting proceedings, book chapters, speeches, outreach articles... Up to now the only available lists of these publications are the appendix in Ros and Prat (1991) with 386 entries, and the University of Barcelona library (http://www.bib.ub.es) with 539 entries including translations and prefaces by Margalef. In addition, many of Margalef's contributions are published in languages other than English, mainly Spanish (Fig. 1), and in journals of limited international scope. In our computer-search driven times, this was evidenced by Valiela and Martinetto (2005) with only 13\% of Margalef's publications surfacing from databases. The paradox is that there may be little opportunity for the scientific community and society at large to read much of the work of one of the most important ecologists of all times.

As part of an effort to preserve the scientific and philosophic legacy of Dr. Margalef, an official count of his contributions was needed. This was initially a

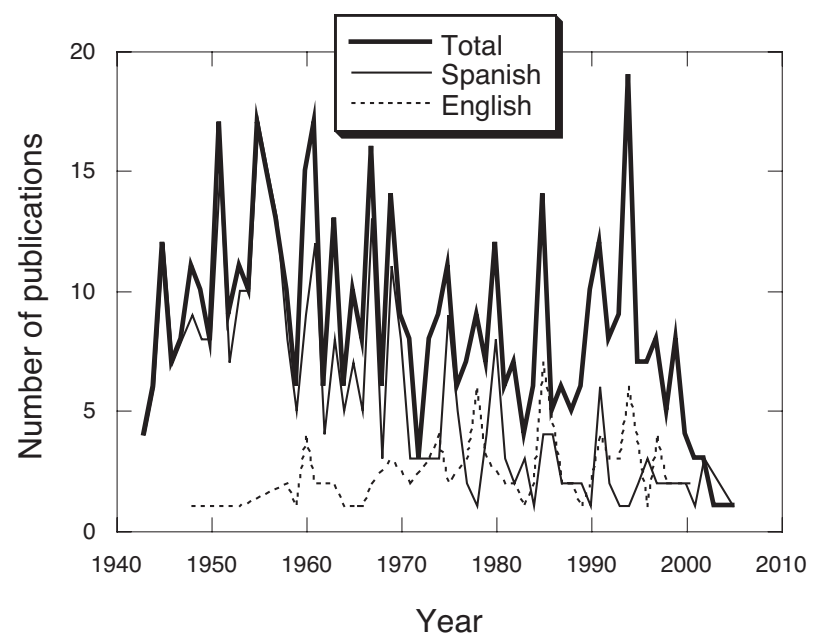

FIG. 1. - Ramon Margalef's publication record expressed as the number of publications per year. one man's effort and, fortunately, some support was soon provided by the Institut de Ciències del Mar in Barcelona in the form of a part-time secretary for a few months. As papers were checked and contrasted with original sources, numerous reference errors were corrected and electronic format versions were generated. The last count (January 2006) is of 587 written contributions, of which 551 have been checked with their original sources. These contributions can now be searched at the Ramon Margalef web site located at the Institut de Ciències del Mar in Barcelona (http://www.icm.csic.es/bio/margalef). Are they completely error free? Surely they are not, as there is always a human behind the scene, scanning, entering the data, etc. Of course, corrections and ammendments are more than welcome. Neither is it an exhaustive count yet as new information about Margalef's contributions keeps appearing almost weekly. But the amount of information in the database is accurate and large enough to warrant its dissemination. I hope you will enjoy Margalef's writings loaded with solid science, huge amounts of scientific integration and insight and plentiful hints about philosophy of science.

\section{References:}

Ros, J. and N. Prat. - 1991. Homage to Ramon Margalef or, Why there is such pleasure in studying nature. Oecologia aquatica, 10. Publicacions Universitat de Barcelona.

Valiela, I. and P. Martinetto. - 2005. The relative ineffectiveness of bibliographic search engines. BioScience, 55: 688-692.

FRANCESC PETERS

Institut de Ciències del Mar (CSIC)

Barcelona, Catalunya, Spain

E-mail: cesc@icm.csic.es 


\section{ANNOUNCEMENT}

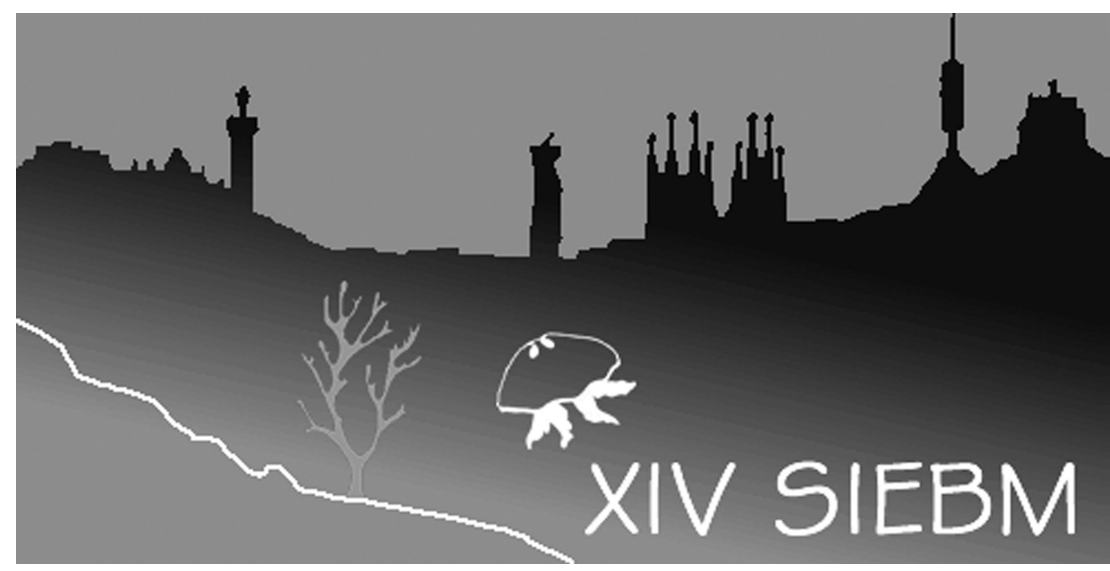

\section{SIMPOSIO IBÉRICO DE ESTUDIOS DE BIOLOGÍA MARINA}

The XIV SIEBM ("Simposio Ibérico de Estudios de Biología Marina") will be held in Barcelona (Cosmocaixa) in September (12th to 15th) 2006. It will be organised by the Resarch Group in Benthic Biology and Ecology of the University of Barcelona. This meeting has a long-standing tradition among Spanish and Portuguese marine biologists, but it is by no means restricted to Iberian scientists. Formerly known as the Iberian Benthic Biology Symposium, this year it has expanded its focus to cover other aspects of marine biology, not just benthos. Special sessions will be devoted to Antarctic studies and to molecular markers in marine biology. The official languages are Spanish, Portuguese, and English. You are most welcome to visit our web page http://www.ub.edu/XIVSIEBM for relevant information, topics, and for online inscriptions and submissions (deadline 15 May).

El XIV SIEBM (Simposio Ibérico de Estudios de Biología Marina) se celebrará en Barcelona (Cosmocaixa) del 12 al 15 de septiembre de 2006. Será organizado por el Grupo de Investigación en Biología y Ecología Bentónicas de la Universidad de Barcelona. Este simposio tiene una larga tradición entre los especialistas españoles y portugueses, pero en ningún modo está limitado a científicos del ámbito ibérico. Conocido en ediciones anteriores como Simposio Ibérico de Estudios del Bentos Marino, este año su enfoque se amplía para cubrir otros aspectos de la biología marina, no sólo bentónica. Los idiomas oficiales serán castellano, portugués e inglés. Se invita a todos los interesados a visitar la página web del Simposio http://www.ub.edu/XIVSIEBM donde encontrarán información sobre el simposio y los temas elegidos, así como la posibilidad de inscribirse y enviar resúmenes online (fecha límite: 15 de mayo). 